Vol. 24, No. 3, Juli 2021, hlm. 476-485

p-ISSN: 1410-9344; e-ISSN: 2549-5631

WARTA LPM

homepage: http://journals.ums.ac.id/index.php/warta

\title{
Penerapan Sketch Up 3D untuk Merancang Konsep Pembuatan Mural Menggunakan Teknik Skala
}

\author{
${ }^{1}$ Erwin Yulianto, ${ }^{2}$ Ali Ahmadi \\ ${ }^{1,2}$ Universitas Langlangbuana \\ Email: ${ }^{1}$ rwinyulianto@yahoo.com, ${ }^{2}$ kang.aliahmadi@gmail.com
}

\section{Article Info}

Submitted: 19 February 2021

Revised: 12 April 2021

Accepted: 5 July 2021

Published: 20 July 2021

Keywords: Citarum Harum, Student Real Work Lecture, Sketch Up 3D, Mural, Scale Technique
Kata kunci: Citarum Harum, Kuliah Kerja Nyata Mahasiswa, Sketch Up 3D, Mural, Teknik Skala

Pollution of the Citarum River is an unfinished homework due to several problems, including damage to land in the watershed, deteriorating water quality as a result of pollution and uncontrolled utilization of water space. The sources of pollution in the waters of the Citarum River come from agricultural, livestock, trade and domestic and industrial waste activities. The Student Real Work Lecture themed Citarum Harum is a Community Service (PKM) activity conducted in Cikutra Village, Bandung City as the implementation of the Tri Dharma of Higher Education. The methods that used in the implementation of Community Service is qualitative method where data collection is carried out using descriptive methods by making observations, interviews, literature studies, discussions, socialization and demonstrations. The programs carried out are monitoring and tracing the Cikutra River together with the GoBer program, socializing the Citarum Harum program in collaboration with the Environment Agency, designing a mural using Sketch Up and implementing a mural with the theme "Sungaiku Indah". The enthusiasm and proactiveness of all village officials, the heads of RW, Youth Organization, PKK, Posyandu, SatGas, Babinsa, Babimkantibnas and the community of Cikutra Village have greatly helped the program that has been implemented. Based on the results of observations for one month, the mural program with the theme "Sungaiku Indah" was able to raise awareness in maintaining the Cikutra River in support of the Citarum Harum program.

Abstrak
Pencemaran Sungai Citarum adalah pekerjaan rumah yang tak
kunjung selesai karena dihadapkan dengan beberapa masalah antara
lain kerusakan lahan di daerah aliran sungai, memburuknya kualitas
air sebagai dampak pencemaran, dan pemanfaatan ruang perairan
yang tidak terkendali. Sumber-sumber pencemaran perairan Sungai
Citarum berasal dari aktivitas pertanian, peternakan, perdagangan,


serta limbah domestik dan industri. Kegiatan Kuliah Kerja Nyata Mahasiswa bertema Citarum Harum merupakan kegiatan Pengabdian Kepada Masyarakat (PKM) yang dilakukan di Kelurahan Cikutra, Kota Bandung sebagai implementasi Tri Dharma Perguruan Tinggi. Metode yang digunakan dalam pelaksanaan PKM yaitu kualitatif di mana pengumpulan data dilakukan menggunakan metode deskriptif dengan melakukan observasi, wawancara, studi literatur, diskusi, sosialisasi, dan demonstrasi. Program yang dilakukan yaitu melakukan pemantauan dan susur Sungai Cikutra bersamaan dengan program GoBer, sosialiasi program Citarum Harum bekerja sama dengan Dinas Lingkungan Hidup, perancangan mural menggunakan Sketch Up dan pelaksanaan Mural dengan tema "Sungaiku Indah". Antusiasme dan proaktif dari segenap petugas kelurahan, para ketua RW, Karang Taruna, PKK, Posyandu, SatGas, Babinsa, Babimkantibnas, dan masyarakat Kelurahan Cikutra sangat membantu program yang telah dilaksanakan. Berdasarkan hasil observasi selama satu bulan, dengan adanya program mural bertema "Sungaiku Indah" mampu meningkatkan kesadaran dalam memelihara Sungai Cikutra dalam mendukung program Citarum Harum.

\section{PENDAHULUAN}

Mengatasi krisis ekologi tidak semata soal teknis, tetapi perlu ditelusuri selukbeluk spiritual manusia, pandangan hidupnya, kesadarannya terhadap alam, dan perilaku ekologisnya yang tetap menjaga keseimbangan alam. Untuk itu diperlukan kecerdasan ekologis (ecological intelligence) manusia, berupa pemahaman dan penerjemahan hubungan manusia dengan seluruh unsur beserta makhluk hidup lain (Utina, 2012). Manusia yang cerdas ekologis menempatkan dirinya sebagai control terhadap lingkungannya (human as in control of the natural environment). Kecerdasan ekologis sebagai empati dan kepedulian yang mendalam terhadap lingkungan sekitar, serta cara berpikir kritis terhadap apa yang terjadi di lingkungan sekitar akibat perlakuan kita (McCallum Ian, 2008).

Sungai Citarum menjadi sumber air irigasi pertanian, Pembangkit Listrik Tenaga Air (PLTA), sumber air baku untuk air minum, serta sebagai lahan perikanan tangkap dan budidaya yang dimanfaatkan penduduk di dua kota dan sepuluh kabupaten di Provinsi Jawa Barat. Sungai Citarum memiliki fungsi dan peran yang sangat penting bagi hidup dan kehidupan di wilayah Jawa Barat (Widodo, 2018). Fungsi hidrologis dari Sungai Citarum adalah menampung curah air hujan yang jatuh di Daerah Aliran Sungai (DAS) dan mendistribusikan ke seluruh wilayah alirannya. Sungai Citarum memiliki peran yang sangat besar dan penting, namun pada sisi lain sungai ini menghadapi berbagai masalah pelik.

Sungai Citarum hari ini dihadapkan pada pencemaran akut yang mengakibatkan kerugian besar terhadap kesehatan, ekonomi, sosial, ekosistem, dan sumber daya lingkungan. Beberapa masalah Citarum antara lain kerusakan lahan di daerah aliran sungai, memburuknya kondisi kualitas air sebagai dampak pencemaran, dan pemanfaatan ruang perairan yang tidak terkendali. Permasalahan pencemaran perairan Sungai Citarum sebagaimana terlihat pada Gambar 1 ini sangat beragam, baik wilayah sebaran maupun jenis pencemarannya. Sumbersumber pencemaran perairan Citarum ini meliputi pencemaran dari aktivitas pertanian, peternakan, perdagangan, serta limbah domestik dan industri yang berkembang pesat.

Berbagai proyek dan program pembenahan masalah Sungai Citarum telah dilakukan oleh pemerintah pusat maupun Provinsi Jawa Barat. Sejak tahun 2014 Pemerintah Provinsi Jawa Barat membuat program yang diberi nama Citarum Bestari yang diperbaharui menjadi Citarum Harum pada bulan Februari 2018. Penanggulangan permasalahan Citarum dengan 


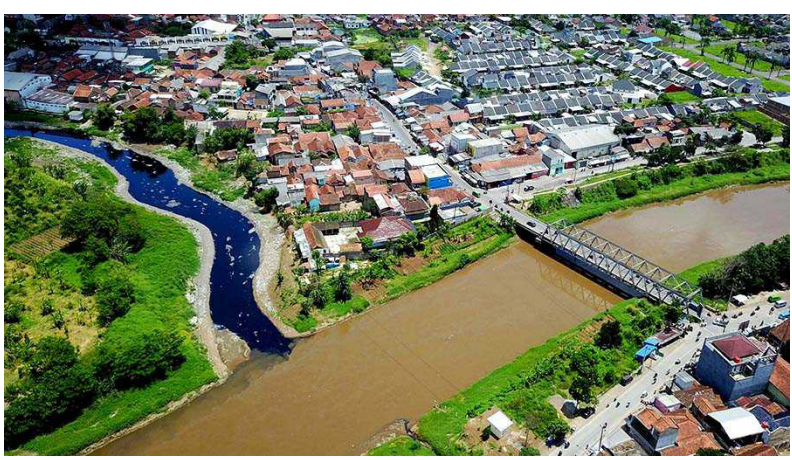

Gambar 1. Daerah Aliran Sungai Citarum Sumber : (Sihombing, 2018)

berbagai kelebihan dan kekurangannya perlu diapresiasi sehingga upaya-upaya perbaikan kondisi dan lingkungan Citarum akan tetap menjadi perhatian dan tetap berlanjut mengingat permasalahan lingkungan pada satu sisi sudah berlangsung lama dan akumulatif dan pada sisi lain penanganannya perlu tahapan-tahapan yang tersusun secara seksama dan sistematik (LIPI, 2019).

Pencemaran sungai melalui limbah terusmenerus terjadi. Padahal daerah perkotaan dengan populasi penduduk yang meledak mengakibatkan sumber air bersih semakin sedikit. Di masa depan sumber daya air akan menghadapi tantangan besar di mana sumber daya air yang tersedia tidak bisa mengimbangi ledakan populasi penduduk. Hal itu berpotensi menimbulkan bencana dan wabah penyakit akibat kurang dan kotornya sumber daya air. Daerah perkotaan dengan pertumbuhan insfratruktur yang cukup besar menyebabkan ketersediaan tanah serapan semakin berkurang. Hal ini membuat kapasitas air bersih yang tersedia juga semakin sedikit. (Sihombing, 2018)

Kegiatan Kuliah Kerja Nyata Mahasiswa (KKNM) bertema Citarum Harum merupakan kegiatan Pengabdian Kepada Masyarakat (PKM) yang dilakukan di Kelurahan Cikutra, Kecamatan Cibeunying Kidul, Kota Bandung sebagai implementasi Tri Dharma Perguruan Tinggi. Kelurahan Cikutra yang terdiri dari 15 RW sebagian besar didominasi oleh pemukiman penduduk dan sebagian lagi merupakan kawasan perdagangan dan pendidikan. Kelurahan Cikutra merupakan daerah kelurahan yang wilayahnya dialiri oleh sungai Cikutra, yang merupakan anak sungai dari Sungai Citarum sebagaimana Denah Aliran Sungai Cikutra pada Gambar 2.

Kondisi perekonomian masyarakat di Kelurahan Cikutra bisa dikatakan cukup baik, profesi warganya pun bervariasi yang paling menonjol adalah sebagian warga yang menjadi pedagang dikarenakan di Kelurahan Cikutra ini terdapat Pasar Cicadas. Oleh karena itu, tidak mengherankan jika banyak masyarakat yang memilih jadi pedagang. Dengan profesi masyarakat yang sebagian menjadi pedagang, kesulitan yang kita temukan adalah sampahsampah yang berasal dari pasar perlu diperhatikan. Aturan hukum sangat sulit ditegakkan di Kelurahan Cikutra ini dikarenakan sulitnya monitoring sepanjang Sungai Cikutra. Banyak sekali sampah rumah tangga dan juga sampah pasar yang dibuang ke Sungai Cikutra. Pelanggaran terhadap pembuangan Sampah sembarangan di kawasan Sungai Cikutra ini akan terus berlanjut, kecuali adanya kesadaran warga untuk membuang sampah pada tempatnya.

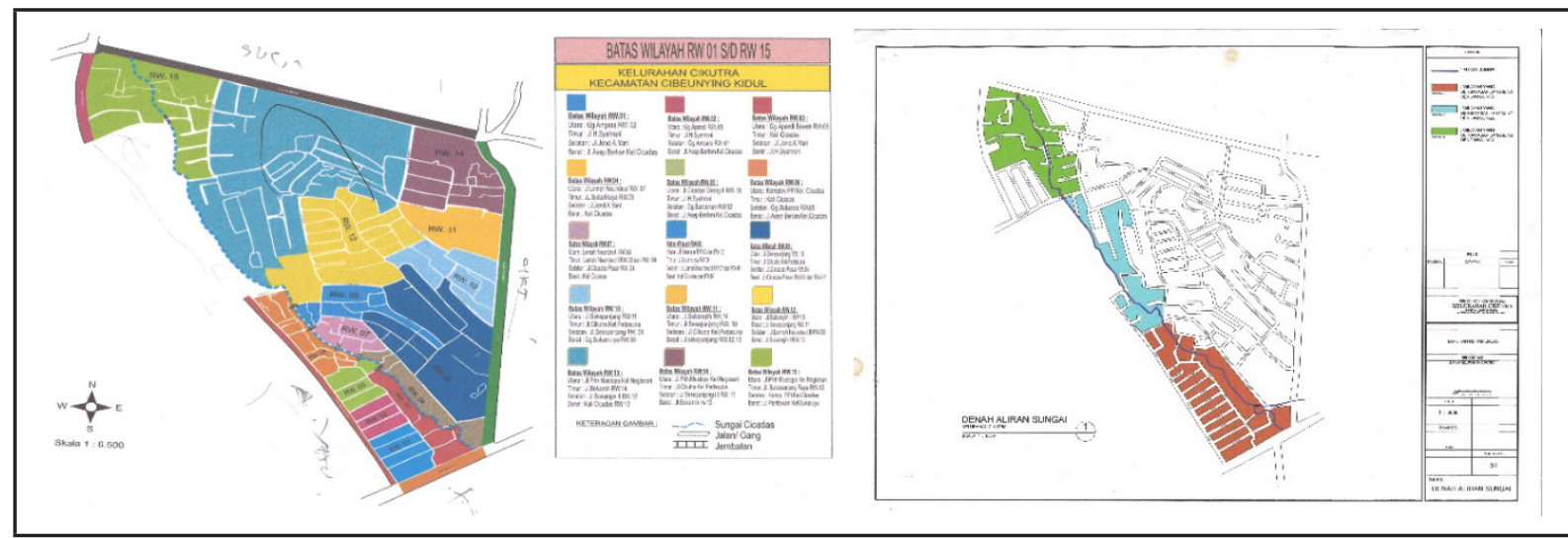

Gambar 2. Batas Wilayah \& Denah Aliran Sungai Cikutra Sumber : (Cikutra, 2019a) 
Sesuai dengan Peraturan Daerah kota Bandung Nomor 03 Tahun 2005 pasal 49 ayat (1) tentang penyelenggaraan Ketertiban, Kebersihan, dan Keindahan. Bahwa pelanggaran membuang sampah di tempat umum atau tepatnya di Sungai akan dijatuhkan pidana denda Rp. 500.000,-

Salah satu skala prioritas pemerintah dalam lingkungan hidup adalah pemerataan pembangunan fasilitas umum dan sosial agar hasil-hasil pembangunan yang dilakukan dapat dinikmati oleh seluruh masyarakat untuk melaksanakan aktivitasnya (Sudarmanto, 2020). Kebersihan lingkungan merupakan pintu gerbang dalam mencapai hidup yang sehat. Hidup sehat merupakan dambaan setiap orang sehingga diperlukan kegiatan yang mendorong masyarakat untuk memulai hidup sehat. Salah satu kegiatan tersebut adalah kampanye hidup sehat melalui program pemberdayaan masyarakat. Kegiatan ini bertujuan untuk menyadarkan masyarakat tentang manfaat hidup bersih dan dampaknya bagi kesehatan, memberikan pengetahuan kepada masyarakat tentang dampak buruk lingkungan yang kotor, dan membantu masyarakat dalam rangka membersihkan lingkungan sekitar tempat tinggal melalui kegiatan aksi lapangan (Khairunissa, 2019). Hal ini sesuai dengan pendapat (Neolaka, 2009) yang menyatakan bahwa kebersihan lingkungan merupakan hal yang tak terpisahkan dari kehidupan manusia dan merupakan unsur yang fundamental dalam ilmu kesehatan. Keterlibatan masyarakat dalam pemeliharaan lingkungan DAS di kelurahan Cikutra dirasakan masih sangat minim sehingga melatarbelakangi perlunya pelaksanaan Pengabdian Kepada Masyarakat dalam bentuk Kegiatan Kuliah Kerja Nyata Mahasiswa (KKNM) pada Kelurahan Cikutra (Cikutra, 2019b).

Topik utama yang akan menjadi fokus kegiatan Pengabdian Kepada Masyarakat ini antara lain yaitu meningkatkan kesadaran masyarakat di Kelurahan Cikutra terkait kebersihanlingkunganhidupkhususnyadiDaerah Aliran Sungai (DAS) Cikutra, melibatkan peran pemerintah dalam meningkatkan kesadaran masyarakat akan pentingnya kebersihan lingkungan hidup, membuat rancangan program yang mampu memberdayakan masyarakat dalam meningkatkan kesadaran akan pentingnya kebersihan lingkungan hidup dan menerapkan programpeningkatankesadaranmasyarakatakan pentingnya kebersihan lingkungan hidup. Salah satu rencana kegiatan PKM yang akan dilakukan yaitu mempercantik dinding di sekitar lokasi sungai dengan mural. Kegiatan ini diharapkan menjadi wadah kreativitas bagi pemerintah dan masyarakat untuk dapat menambah keindahan lingkungan sekitar yang fokus mengisi ruang kosong di lingkungan warga. Dengan seni mural tentu dapat menambah keindahan kawasan sehingga kesadaran masyarakat untuk menjaga lingkungan diharapkan tumbuh seiring kondisi kawasan sungai yang terus dipercantik (Kumparan, 2019).

Hal tersebut senada dengan kegiatan Mahasiswa Kuliah Kerja Nyata (KKN) UPI yang melakukan upaya memberikan kesadaran kepada masyarakat akan pentingnya menjaga lingkungan tetap bersih dan sehat. Salah satu bentuk kepedulian mahasiswa UPI untuk meningkatkan kesadaran masyarakat adalah melakukan mural (Kompasiana, 2020). Tujuan pelaksanaan Pengabdian Kepada Masyarakat akan berbentuk Kegiatan Kuliah Kerja Nyata Mahasiswa (KKNM) antara lain melakukan aktivitas pemantauan dan penyusuran Sungai Cikutra melalui program Gorong-Gorong Bersih (GoBer) sekaligus mengumpulkan bahanbahan dan materi rancangan mural yang akan dilakukan, melakukan sosialiasi Program Citarum Harum bekerja sama dengan pemerintah untuk mengedukasi warga akan pentingnya kebersihan lingkungan hidup di daerah aliran Sungai Cikutra, membuat perancangan mural berdasarkan hasil pengamatan langsung (survei lapangan) kawasan yang menjadi objek penelitian dan menerapkan program mural di beberapa titik yang sudah ditentukan sehingga dapat memberikan dampak positif baik bagi masyarakat Kelurahan Cikutra.

\section{METODE}

Metode pelaksanaan yang digunakan dalam PKM ini yaitu metode kualitatif. Penelitian kualitatif adalah penelitian yang bermaksud untuk memahami fenomena tentang apa yang dialami oleh subjek penelitian misalnya perilaku, persepsi, motivasi, tindakan, dll secara holistik, dan dengan cara deskripsi dalam bentuk kata- 
kata dan bahasa, pada suatu konteks khusus yang alamiah dan dengan memanfaatkan berbagai metode alamiah (Moleong, 2006).

Pelaksanaan kegiatan Pengabdian Kepada Masyarakat dalam bentuk Kegiatan Kuliah Kerja Nyata Mahasiswa (KKNM) pada Kelurahan Cikutra dilakukan selama 4 (empat) bulan dimulai sejak bulan Juli 2019 s.d. Oktober 2019. Tahapan kegiatan yang dilakukan pada kegiatan KKNM Citarum Harum di Kelurahan Cikutra terbagi ke dalam tiga kategori, yaitu tahapan persiapan yang dilakukan selama dua minggu, tahapan pelaksanaan yang dilakukan selama tiga bulan, dan tahapan pelaporan yang dilakukan selama dua minggu.

Pada tahapan persiapan, dilakukan pengumpulan data dengan menggunakan metode deskriptif seperti melakukan observasi, wawancara, dan studi literatur, diskusi, sosialisasi, dan demonstrasi. Pada tahapan pelaksanaan, kegiatan KKNM diisi dengan program-program unggulan, antara lain melakukan pemantauan dan susur Sungai Cikutra bersamaan dengan program GorongGorong Bersih (GoBer), sosialiasi program Citarum Harum bekerja sama dengan Dinas
Lingkungan Hidup \& Kebersihan, perancangan mural menggunakan Sketch $U p$, dan pelaksanaan kegiatan Mural dengan tema "Sungaiku Indah". Tahap pelaporan merupakan tahapan akhir pelaksanaan PKM KKNM di Kelurahan Cikutra yang mewajibkan adanya keluaran dalam bentuk Laporan Akhir dan Laporan Kemitraan Masyarakat. Adapun metodologi pelaksanaan PKMM KKNM di Kelurahan Cikutra dapat dilihat pada Gambar 3.

Adapun waktu dan pelaksanaan dari program Pengabdian Kepada Masyarakat (PKM) ini dapat dilihat pada Tabel 1.

\section{HASIL DAN PEMBAHASAN}

Kegiatan pengabdian kepada masyarakat ini diikuti oleh 37 (tiga puluh tujuh) mahasiswa dan 47 (empat puluh tujuh) jajaran petugas di Kelurahan, organisasi-organisasi kepemudaan, dan sosial yang terlibat serta masyarakat Kelurahan Cikutra. Hasil kegiatan yang telah kami lakukan antara lain:

a. Pemantauan dan Susur Sungai Cikutra bersamaan dengan program GorongGorong Bersih (GoBer).

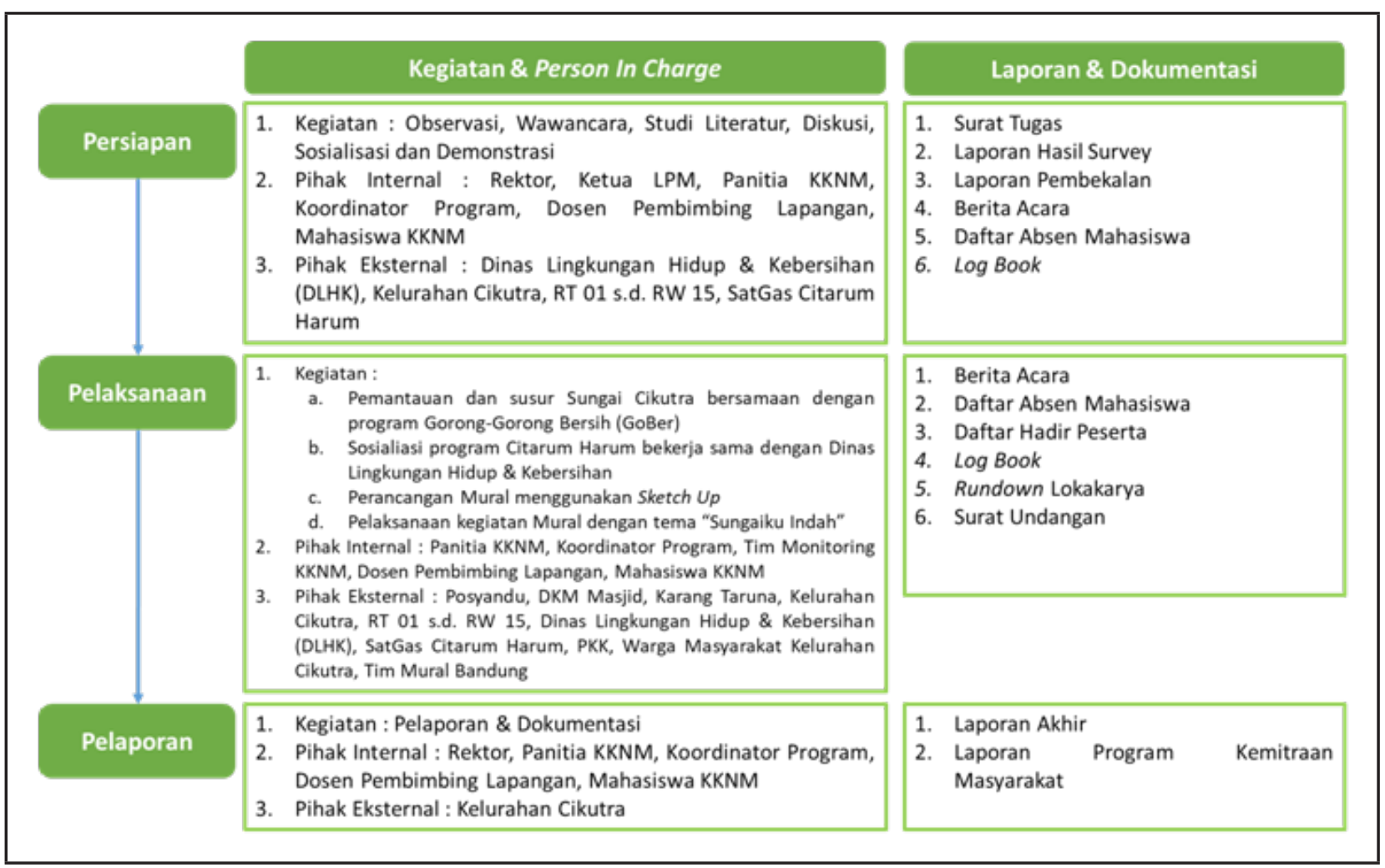

Gambar 3. Metodologi Pelaksanaan 
Tabel 1. Waktu Pelaksanaan PKM

\begin{tabular}{|c|c|c|c|c|c|c|c|c|c|c|}
\hline \multirow{2}{*}{ Kegiatan } & \multicolumn{4}{|c|}{ Juli 2019} & \multirow{2}{*}{$\begin{array}{c}\text { Agust } \\
2019\end{array}$} & \multirow{2}{*}{$\begin{array}{c}\text { Sep } \\
2019 \\
\end{array}$} & \multicolumn{4}{|c|}{ Oktober 2019} \\
\hline & M1 & M2 & M3 & M4 & & & M1 & M2 & M3 & M4 \\
\hline Persiapan Internal \& Eksternal & V & V & & & & & & & & \\
\hline Pelaksanaan & & & $\mathrm{V}$ & $\mathrm{V}$ & $\mathrm{V}$ & V & $\mathrm{V}$ & $\mathrm{V}$ & & \\
\hline $\begin{array}{l}\text { Pemantauan dan susur Sungai Cikutra bersamaan } \\
\text { dengan program Gorong-Gorong Bersih (GoBer) }\end{array}$ & & & $\mathrm{V}$ & $\mathrm{V}$ & & & & & & \\
\hline $\begin{array}{l}\text { Sosialiasi program Citarum Harum bekerja sama } \\
\text { dengan Dinas Lingkungan Hidup \& Kebersihan }\end{array}$ & & & & & $\mathrm{V}$ & $\mathrm{V}$ & & & & \\
\hline Perancangan Mural menggunakan Sketch Up & & & & & & V & & & & \\
\hline $\begin{array}{l}\text { Pelaksanaan kegiatan Mural dengan tema "Sungaiku } \\
\text { Indah" }\end{array}$ & & & & & & & $\mathrm{V}$ & $\mathrm{V}$ & & \\
\hline Pelaporan \& Dokumentasi & & & & & & & & & V & V \\
\hline
\end{tabular}

Pada kegiatan ini, tim KKNM melakukan pemantauan / observasi dan susur bantaran Sungai Cikutra setelah mendapatkan izin dari Kelurahan Cikutra dan diketahui oleh para Ketua RW setempat. Selanjutnya kegiatan GoBer (Gorong-Gorong Bersih) yang dilakukan langsung di Sungai Cikutra bertujuan untuk melakukan observasi aliran anak sungai di sepanjang Kelurahan Cikutra sekaligus mengimplementasikan kegiatan pengabdian kepada masyarakat Kelurahan Cikutra dalam hal menjaga kebersihan aliran anak sungai.

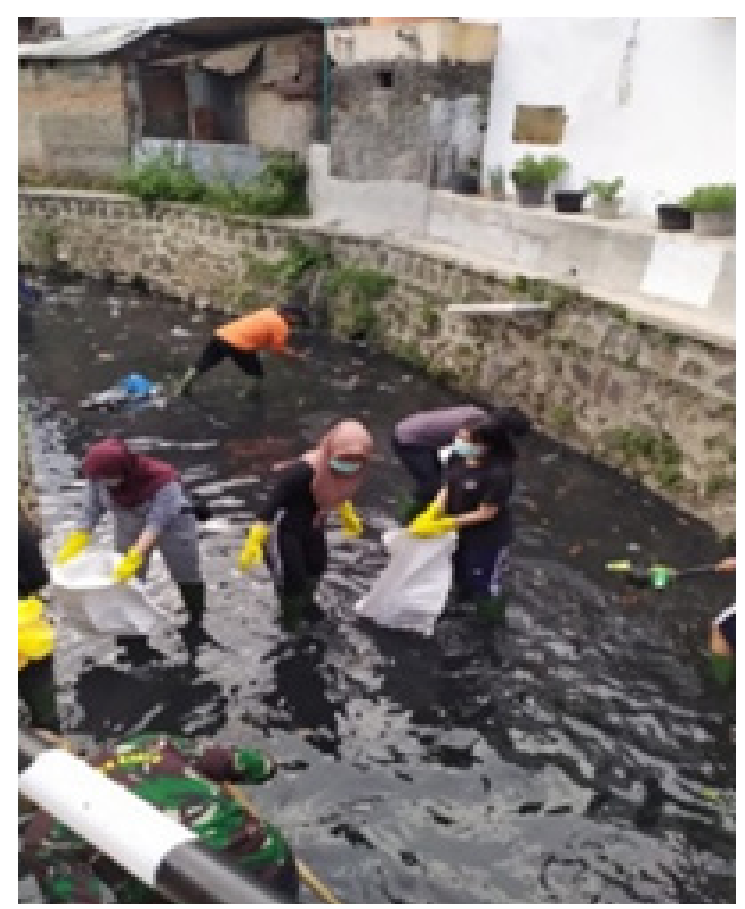

Gambar 4. Kegiatan Pemantauan \& Susur Sungai Cikutra Bersama Program GoBer
Hasil yang didapat dari kegiatan penyisiran adalah bahan mentah desain yang akan dijadikan materi perancangan mural "Sungaiku Indah" sekaligus dengan membuat pengukuran menggunakan teknik skala. Selain itu, pelaksanaan GoBer juga menjadikan kondisi lingkungan di Sungai Cikutra menjadi jauh lebih bersih dibandingkan sebelumnya. Adapun dokumentasi penyisiran dapat dilihat pada Gambar 4.

b. Sosialiasi Program Citarum Harum Bekerja Sama dengan Dinas Lingkungan Hidup \& Kebersihan

Kegiatan sosialisasi program Citarum Harum disampaikan oleh Kepala Dinas DLHK Kota Bandung mengenai kegiatankegiatan yang dilakukan untuk mendukung kesuksesan pelaksanaan Program Citarum Harum seperti revitalisasi Sungai Cikutra, gerakan KangPisMan yaitu Kang (kurangi sampah makanan), Pis (pilah sampah), dan Man (manfaatkan sampah menjadi nilai jual).

Hasil yang didapat dari kegiatan ini adalah daftar presensi dan berita acara kegiatan sosialiasi program Citarum Harum yang disampaikan kepada pihak Kelurahan Cikutra dan Dinas Lingkungan Hidup. Melalui kegiatan sosialisasi ini, diharapkan kesadaran masyarakat akan pentingnya lingkungan hidup akan meningkat. Selanjutnya dokumentasi sosialisasi dapat dilihat pada Gambar 5 berikut. 


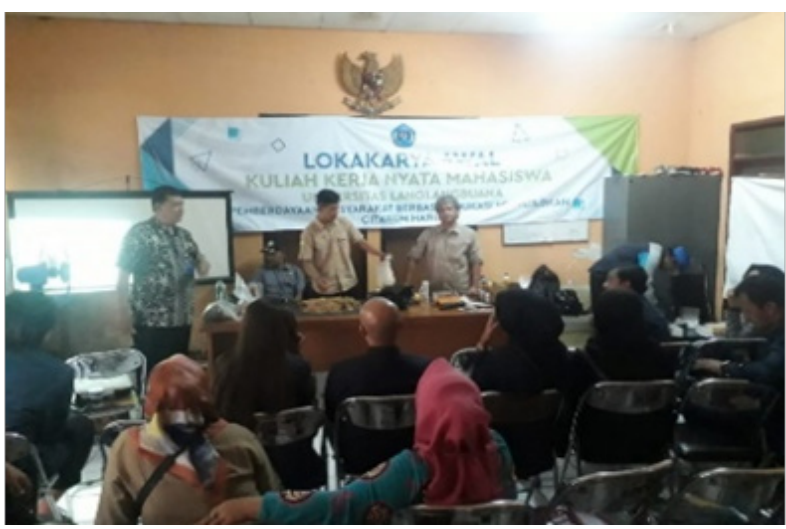

Gambar 5. Sosialiasi Program Citarum Harum Bersama DLHK Kota Bandung

c. Perancangan Mural Menggunakan Teknik Skala pada Aplikasi Sketch Up

Pengumpulan data Sungai Citarum menggunakan metode Site Reconnaissance yaitu sebuah metode yang dilakukan dengan pengamatan langsung (survei lapangan) kawasan yang menjadi objek penelitian. Metode ini bertujuan untuk mendapatkan gambaran umum kawasan dan masalah yang ada di dalamnya sehingga mendapatkan data kualitatif.

Perancangan mural dilakukan berdasarkan hasil pemantauan / observasi dan susur bantaran Sungai Cikutra. Kegiatan tersebut bertujuan untuk mengetahui kondisi existing lingkungan di sekitar bantaran sungai Cikutra, mengetahui potensi-potensi yang bisa dikembangkan di sekitar bantaran Sungai Cikutra dan mengusulkan solusi yang bisa diterapkan dalam mengatasi permasalahan lingkungan di sekitar bantaran sungai di kawasan Kelurahan Cikutra. Berikut ini tahap-tahap membuat mural dan cara membuat mural yang baik dan benar untuk menghasilkan karya terbaik:
1) Tekan tepi pertama dengan cat
2) Celupkan roller kedalam cat
3) Gulung cat ke dinding membentuk "W" atau "M".
4) Biarkan cat mengering beberapa jam
5) Selesaikan beberapa garis dengan lapisan cat
6) Perbaiki dengan cat pelapis kedua, jika dibutuhkan

Selanjutnya, perancangan mural akan menggunakan tools Sketch Up, yaitu sebuah program pemodelan 3D yang dirancang untuk arsitek, insinyur sipil, pembuat film, game developer dan profesi terkait. Sketch Up juga mencakup fitur-fitur untuk memfasilitasi pembuatan model. Sketch $U p$ dikembangkan oleh perusahaan Startup @ Last Software, Boulder, Colorado yang dibentuk pada tahun 1999. Sketch Up pertama kali dirilis pada bulan Agustus 2000 sebagai tujuan umum alat pembuatan konten 3D. Pada tanggal 14 Maret 2006, Google mengakuisisi @ Last Software, karena Google tertarik untuk membuat plug in untuk Vektor 3D Layout termasuk peralatan, serta alat-alat tata letak yang dimaksudkan untuk memudahkan bagi para profesional untuk membuat presentasi tanpa berkerjasama dengan pihak ketiga program presentasi. (Arrasyid, 2019)

Sketch Up menyediakan 10 peralatan sederhana. Seluruh peralatan tersebut dapat Anda gunakan untuk membuat model. Peralatan orbit, pan, dan zoom termasuk kategori peralatan utama. Peralatan tersebut dapat Anda gunakan untuk menggeser tampilan dan mengubah sudut pandang. Beberapa fungsi yang dimiliki oleh Sketch Up antara lain membuat garis, membuat bentuk dua dimensi seperti lingkaran, kotak, atau segi lima, membuat objek tiga dimensi, melakukan panning dan orbiting, yaitu melihat objek dari berbagai perspektif, memindahkan dan memutar objek dengan menggunakan tool Move dan Rotate, mewarnai objek, memperbesar tampilan menggunakan tool Zoom, menyediakan berbagai model jadi yang dapat digunakan sesuai keperluan di $3 D$ Warehouse, menggunakan penanda konstruksi untuk mensejajarkan objek, menggunakan peralatan tingkat lanjut Sketch Up seperti resizing tool, uniform tool, curve tool, follow me tool, text tool, angle tool dan measuring tape tool, dan menyediakan banyak panduan untuk membantu Anda membuat gedung, struktur, dan lain-lain (Lloyd, 2019). 


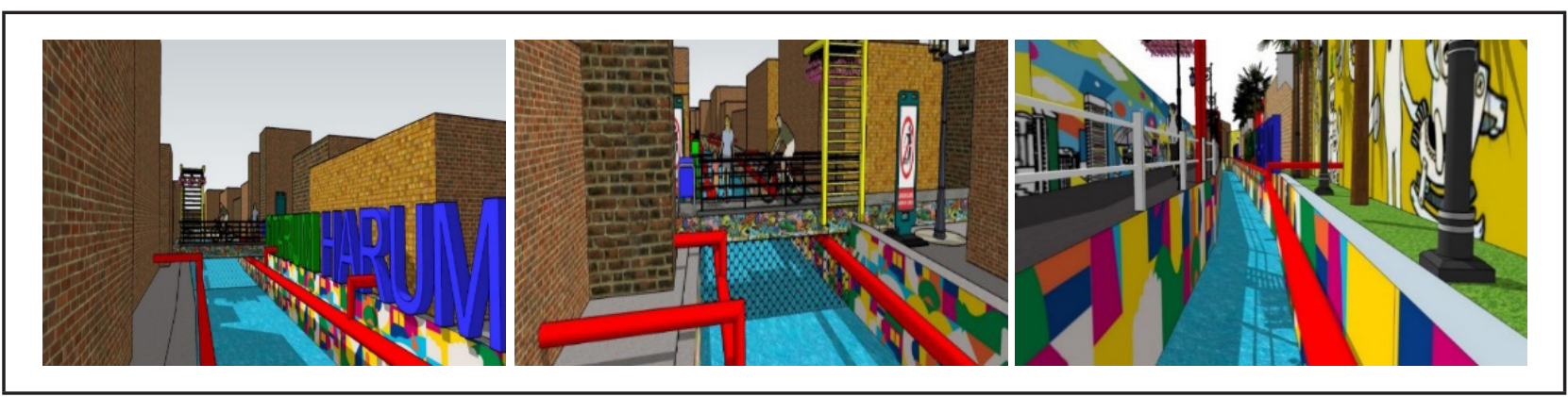

Gambar 6. Perancangan Mural Menggunakan Sketch Up

Dalam membuat mural, terdapat beragam teknik untuk menyelesaikan suatu lukisan mural yang dibedakan menurut tingkat kesulitannya, antara lain teknik proyektor, teknik kertas karbon, teknik skala, dan teknik langsung. Pada perancangan mural ini, yang akan digunakan adalah teknik skala, yaitu teknik yang digunakan dalam menggambar peta yakni menggunakan perbandingan skala. Tujuannya sendiri agar gambar bisa sama dan bisa diperbesar dari ilustrasi ke dinding.

Hasil dari kegiatan Perancangan Mural yaitu desain yang akan diimplementasikan oleh Tim PKM KKNM melalui kegiatan mural di Kelurahan Cikutra. Dokumentasi Perancangan Mural Menggunakan Sketch Up dapat dilihat pada Gambar 6 berikut.

d. Pelaksanaan Kegiatan Mural Dengan Tema "Sungaiku Indah".

Mural dilaksanakan untuk mempercantik sebuah kawasan dengan harapan setelah di mural di beberapa titik yang sudah ditentukan dapat memberikan dampak positif terkait kesadaran hidup bersih baik bagi warga sekitar maupun masyarakat umum yang lewat dan datang ke kawasan tersebut melalui pesan-pesan yang di sampaikan melalui Mural yang sudah di buat di sepanjang ruas dinding jalan. Dampak positif lainnya yaitu terkait dengan pemberdayaan ekonomi masyarakat sekitar menjadi lebih baik dengan adanya tamutamu dari luar yang sengaja datang untuk ber-selfie di beberapa objek mural yang sudah dibuat. Mural di Indonesia sudah sangat lama ada bahkan ribuan tahun yang lalu sudah ada. Hal ini bisa kita lihat dari dinding-dinding goa pada stalaktit dan stalakmit di mana manusia dahulu (manusia purba) sudah melukis dengan bahan alami dari getah pohon maupun darah binatang (Ifwandi, 2020; Luthfi, 2020).

Mural adalah gambar atau lukisan di atas media dinding atau media luas lainnya yang bersifat permanen. Mural bertujuan untuk menanamkan budaya Perilaku Hidup Bersih dan Sehat (PHBS) di Kelurahan Cikutra, Kota Bandung bertujuan untuk membantu pemerintah dalam memberikan sosialisasi kepada warga supaya berperilaku hidup bersih dan sehat. Kegiatan Pengabdian kepada Masyarakat kali ini memanfaatkan dinding untuk melukis mural yang dapat dijadikan sarana sosialisasi dengan cara mengingatkan warga masyarakat untuk hidup bersih dan sehat. Selain itu, mural juga dapat digunakan untuk spot swafoto atau rekreasi bagi masyarakat.

Kegiatan mural ini melibatkan seluruh mahasiswa KKNM dibantu dengan perwakilan petugas kelurahan, perwakilan dari RT RW, perwakilan Karang Taruna, Tim SatGas, Tim Babinsa, Babimkantibnas, dan sebagian masyarakat Kelurahan Cikutra. Antusiasisme warga membuat pelaksanaan kegiatan mural ini berjalan dengan lancar. Hasil kegiatan mural yaitu lukisan dinding yang bertemakan "Sungaiku Indah" pada beberapa titik dinding di kelurahan Cikutra. Dokumentasi Kegiatan Mural "Sungaiku Indah" dapat dilihat pada Gambar 7.

Program Kegiatan Mural dengan menggunakan Teknik Skala merupakan sebuah cara/teknik yang berbeda dalam mengedukasi warga tentang pentingnya menjaga lingkungan sekitar khususnya untuk daerah yang berada di dekat bantaran Sungai Cikutra. Dampak dan manfaat mural Perilaku Hidup Bersih dan Sehat (PHBS) 


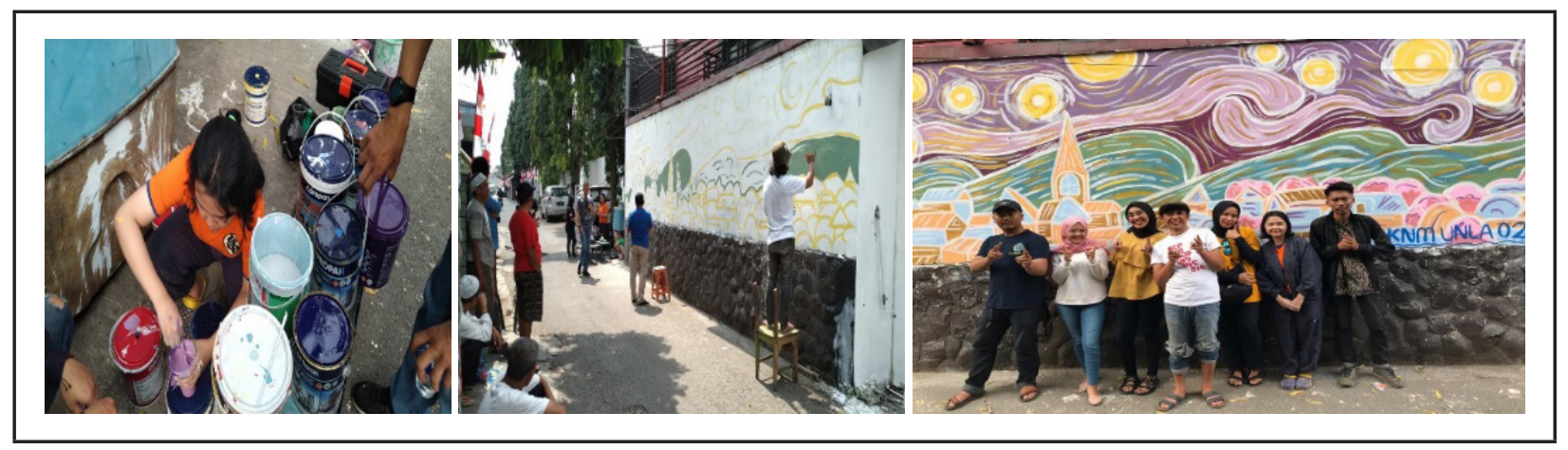

Gambar 7. Kegiatan Mural dengan Tema "Sungaiku Indah".

Kelurahan Cikutra, Kota Bandung ini adalah (Karyanto, Budi; Lombogia, Franky; Hermawati, 2020) :

1) Lokasi mural yang awalnya tidak bermanfaat bahkan kumuh menjadi bersih, indah dipandang dan bermanfaat.

2) Dengan adanya mural PHBS maka masyarakat selalu diingatkan untuk berperilaku hidup sehat.

3) Lokasi mural bisa menjadi swafoto da rekreasi kecil bagi warga.

4) Pemanfaatan dinding dan pemilihan lokasi yang tepat ternyata bisa memperindah lingkungan dan menjadikan pendorong warga masyarakat untuk berperilaku hidup bersih dan sehat.

\section{SIMPULAN}

Berdasarkan program-program yang telah dilaksanakan selama Kuliah Kerja Nyata Mahasiswa dengan tematik Citarum Harum di Kelurahan Cikutra, dapat disimpulkan bahwa pemantauan dan Susur Sungai Cikutra berhasil mengumpulkan bahan mentah yang akan dijadikan materi perancangan mural "Sungaiku Indah" dengan menggunakan pengukuran menggunakan Teknik skala bersama dengan program Gorong-Gorong Bersih (GoBer) sebagai bentuk Pengabdian Kepada Masyarakat Kelurahan Cikutra dalam hal kebersihan aliran anak sungai. Selanjutnya sosialiasi Program Citarum Harum bekerja sama dengan Dinas Lingkungan Hidup \& Kebersihan mengedukasi warga akan pentingnya revitalisasi Sungai Cikutra melalui gerakan KangPisMan yaitu
Kang (kurangi sampah makanan), Pis (pilah sampah), dan Man (manfaatkan sampah menjadi nilai jual). Perancangan mural menggunakan Sketch Up dengan menggunakan metode Site Reconnaissance dilakukan dengan pengamatan langsung (survei lapangan) kawasan yang menjadi objek penelitian sehingga gambaran umum kawasan Sungai Citarum dapat dianalis dan dikaji. Program mural (Seni Melukis Dinding Tembok) mempercantik sebuah kawasan dengan harapan setelah dimural di beberapa titik yang sudah di tentukan, maka kawasan tersebut bisa memberikan dampak positif baik bagi warga sekitar atau pun untuk masyarakat umum yang melewati dan datang ke kawasan tersebut.

Kegiatan mural ini menjadi media sosialisasi bagi warga masyarakat terhadap pentingnya hidup sehat dengan menerapkan Perilaku Hidup Bersih dan Sehat (PHBS) dalam hidup seharihari serta membangun sinergitas antara civitas akademika dan masyarakat dalam mewujudkan kebersihan lingkungan dan memanfaatkan media berupa dinding sebagai media mural PHBS.

\section{PERSANTUNAN}

Ucapan terima kasih kami sampaikan kepada Lembaga Penelitian dan Pengabdian Masyarakat, Universitas Muhammadiyah Surakarta, khususnya kepada tim panitia dan pengurus OJS Warta LPM. Terima kasih juga kepada STIE Ekuitas yang telah memfasilitasi pelaksanaan konferensi nasional bagi kami serta Universitas Langlangbuana dan Kelurahan Cikutra, Kota Bandung yang telah turut serta dalam membantu terlaksananya kegiatan Pengabdian Kepada Masyarakat ini melalui program Kuliah Kerja Nyata Mahasiswa. 


\section{REFERENSI}

Arrasyid, M. A. (2019). Pengenalan Google Sketch-Up: Sejarah Google Sketch-Up. https:// designofmanufactures.wordpress.com/2016/08/05/pengenalan-google-sketchup-sejarahgoogle-sketchup/

Cikutra, K. (2019a). Batas Wilayah RW01 s.d. RW15. Dokumen Resmi Kelurahan Cikutra.

Cikutra, K. (2019b). Denah Aliran Sungai. Dokumen Resmi Kelurahan Cikutra.

Ifwandi, N. (2020). Pengertian Mural, Sejarah, Perkembangan \& Perbedaan Mural dan Graffiti. https:// www.imural.id/blog/pengertianmural/

Karyanto, Budi; Lombogia, Franky; Hermawati, A. (2020). Mural sebagai Sosialisasi Perilaku Hidup Bersih \& Sehat di Kecamatan Karawaci, Kota Tangerang, Provinsi Banten. Jurnal Aplikasi \& Inovasi Ipteks, 3(2), 54-61.

Khairunissa, D. (2019). Kampanye Kebersihan Lingkungan melalui Program Kerja Bakti Membangun Desa di Lombok Utara. Jurnal Pendidikan \& Pengabdian Masyarakat, 2(2), 230-234.

Kompasiana. (2020). Meningkatkan Kesadaran Masyarakat akan Kebersihan Sungai dan Lingkungan Melalui Ilustrasi Mural. https://www.kompasiana.com/ hanifshobirin/5e2 efcc9d541df299a005b62/meningkatkan-kesadaran-masyarakat-akankebersihan-sungai-dan-lingkungan-melalui-ilustrasi-mural

Kumparan. (2019). Mempercantik Sungai di Denpasardengan Mural. https://kumparan.com/kanalbali/ mempercantik-sungai-di-denpasar-dengan-mural-1r3UDSkSVad/full

LIPI. (2019). Citarum Harum dan Harapan Pemulihan Daerah Aliran Sungai. http://lipi.go.id/ siaranpress/citarum-harum-dan-harapan-pemulihan-daerah-aliran-sungai-/21575

Lloyd, J. (2019). Cara Menggunakan Sketch-Up. https://id.wikihow.com/Menggunakan-SketchUp

Luthfi, W. (2020). Perbedaan Mural dan Graffiti, Gambar yang Percantik Gang dan Jalanan / Good News From Indonesia. https://www.goodnewsfromindonesia.id/2020/03/19/ perbedaan-muraldangraffiti-gambar-yang-percantik-gang-dan-jalanan

McCallum Ian, L. W. (2008). Ecological Intelligence - Rediscovering Ourselves in Nature. Fulcrum.

Moleong, J, L. (2006). Metodologi Penelitian Kualitatif. PT. Remaja Rosdakarya.

Neolaka, A. (2009). Kesadaran Lingkungan. Rineka Cipta.

Sihombing, S. S. (2018). Pelestarian Sungai Citarum Harum melalui Intalasi Pengolaan Air Limbah (IPAL) \& Penegakan Hukum terhadap Mafia Sungai. https://kompasiana. com/08051998/5b0d703dcf01b46fbc382083/pelestarian-sungai-citarum-harum-melaluiintalasi-pengolaan-air-limbah-ipal-dan-penegakan-hukum-terhadap-mafia-sungai?page=all

Sudarmanto, D. (2020). Konsep Dasar Pengabdian Kepada Masyarakat. Yayasan Kita Menulis.

Utina, R. (2012). Kecerdasan Ekologis dalam Kearifan Lokal Masyarakat Bajo Desa Torosiaje Provinsi Gorontalo. Kecerdasan Ekologis Dalam Kearifan Lokal Masyarakat Bajo Desa Torosiaje Provinsi Gorontalo, 14-20.

Widodo, J. (2018). Percepatan Pengendalian Pencemaran dan Kerusakan Daerah Aliran Sungai Citarum. 